\title{
Evaluation of transport networks as disaster evacuation routes (Case study of flood disaster in Huamual Sub-District, Maluku)
}

\author{
Ahmad Munawar ${ }^{1 *}$, Joko Sujono ${ }^{1}$, Adam Pamudji Rahardjo ${ }^{1}$, Joko Murwono $^{1}$, and Ahmad \\ Nur Hamid ${ }^{1}$ \\ ${ }^{1}$ Gadjah Mada University, Depart. of Civil and Environmental Engineering, Yogyakarta, Indonesia
}

\begin{abstract}
As the global warming occurs, the effects of rainy and dry seasons in Indonesia have changed. Extreme rainfall causes some several disasters of such as flash floods and landslides which cause loss of life, damage to facilities, infrastructure and transport routes, as well as damage to the economy. The method used in this study began with a field survey conducted in Dusun Nasiri, Dusun Mange-mange, and Dusun Hatamanu to determine the condition of the road network between the centre of local government to the affected villages. In addition, laboratory tests were carried out in the Transport Laboratory, Gadjah Mada University, Yogyakarta. This study produced several maps by using ArcGIS software, and the laboratory tests produce findings on the feasibility of local materials for the restoration of the raod network. The maps showed the affected area and the routes for evacuation and the distribution of logistical, medical and paramedical aid, CFA, Makassar.
\end{abstract}

\section{Introduction}

Indonesia is an archipelagic country located between the Asian and Australian continents. The country had only two changes of season, rainy and dry. The extreme rainfall has caused some disasters, such as flash floods and landslides [1]. The major causes of the flash floods are heavy rainfall and sedimentation. Another cause is deforestation in the region: the land is made bare and no longer functions as a place for the absorption of rainwater [1].

The loss of life is the main damage caused by flash floods. Other impacts of flash floods are damaged facilities, infrastructure and transport routes. For example, in 2012 and 2013, flood disasters hit Maluku province. They occurred not only in the City of Ambon, but also in Central Maluku District and Western Seram District. Data from the Regional Disaster Management Agency (BPBD) of Ambon City shows that a total of 18 people died, 5,420 houses were submerged in water, and 2,170 families, or as many as 4,718 people, were evacuated. The highest level that the flood reached was seven metres, and the most severe

\footnotetext{
*Corresponding author: munawar@ugm.ac.id
} 
flooding was in Dusun Nasiri, Dusun Mange-mange, Dusun Hatamanu, Desa Luhu, Huamual Sub-District, Western Seram District. BPBD data shows 5 people dead, 1,200 people evacuated, and 154 houses severely damaged. In addition to the loss of life, the flash floods in the region also damaged infrastructure buildings and public facilities, such as embankments, irrigation canals, road networks and bridges.

The scale of the many losses suffered calls for preventive action to minimize the adverse impacts of the flash floods [2]. Evacuation routes and evacuation activities are, therefore, the most important points to be analyzed [3], and require geospatial data and regional information for networking analysis [4]. Hazard maps and evacuation signage should be used for analysis and to provide information [5]. One preventive action which can be carried out immediately is to prepare the road network to support expeditious evacuation from flash floods. This would also be beneficial by encouraging economic growth in Maluku [6]. Therefore, it is necessary to investigate the feasibility of the road network used for evacuation and the mobilization of aid to the victims of natural disasters [7].

The evacuation process requires accessible routes to evacuate victims to safer areas. These are called the evacuation routes [8]. Evacuation routes can be reached by land, air, and sea transport [9]. The three components of evacuee or volunteer access to the evacuation places [10] are:

- The current state of the road network in the affected areas.

- The speed with which evacuees, volunteers and logistics can move to the evacuation places.

- The trip period is the time required by the evacuees, volunteers and logistics to reach the evacuation places.

The choice of route depends on travel time, travel cost, comfort and safety [11]. Transport both for the evacuation and the general economy will require a road surface able to carry existing transport loads. A road is constructed in several courses: the surface course which consists of the binder course and wearing course, the base course, the sub-base course and the subgrade. The layers of the completed construction will have some of the following functions [12]:

- To support and spread the load of the vehicles (traffic load);

- To provide some comfort with a flat surface course;

- To provide some roughness so that the vehicle does not slip;

- To provide a wearing course

To protect the underlying courses from water and weather, that can damage them.

\section{Method and Analysis}

There are several steps involved in the conduct of this study. The first is to carry out a field survey in the study area to determine the condition of the road network from the centre of local district government centre to the disaster- affected villages. This step includes testing in the laboratory a sample of the aggregate used in the road construction. The laboratory test will be conducted in the Department of Civil and Environmental Engineering, Faculty of Engineering, Gadjah Mada University, Yogyakarta, with the use of a guide book from the Ministry of Public Works, Directorate General of Highways.

The road network survey is conducted along the road from the Centre of Local District Government of Western Seram to the flash flood site with assistance of GPS devices and a camera.

The GPS data will be input into the ArcGIS software to evaluate the road network. 
The location of the disaster-prone area in Dusun Nasiri, Dusun Mange-mange and Dusun Hatamanu in Huamual Sub-District, is a valley flanked by two hills. To determine the evacuation routes for the disaster victims, the survey first needs to know the affected areas by mapping them with the help of ArcGIS software. An example of a disaster map of Dusun Nasiri is shown in Fig. 1.

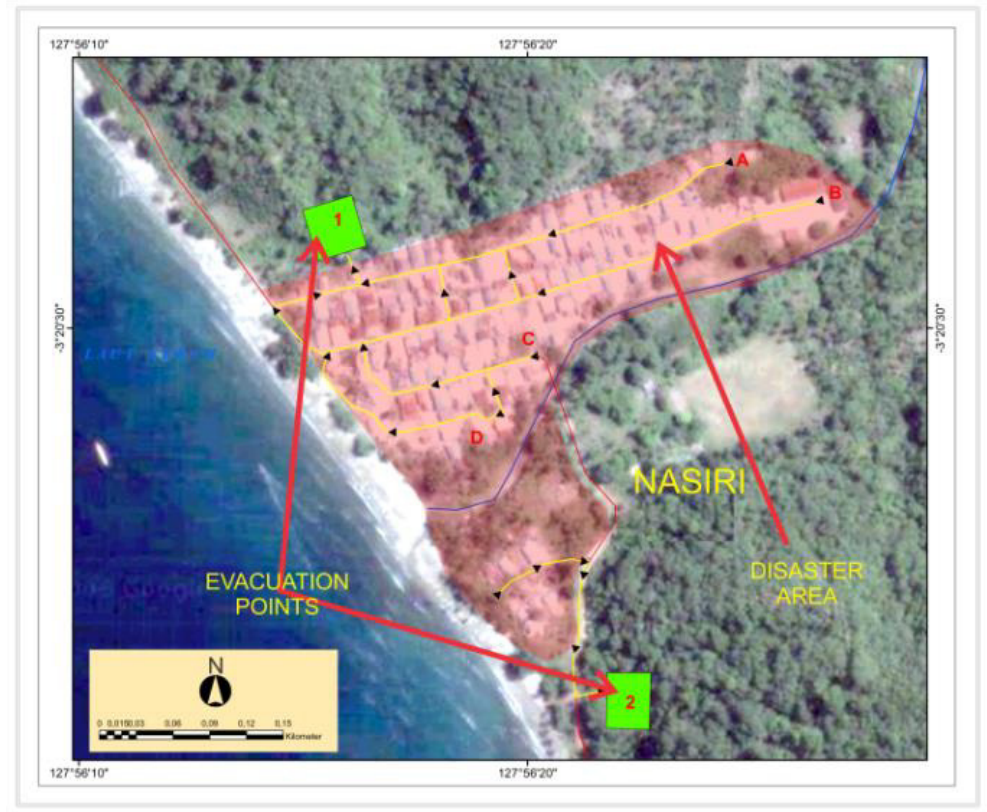

Fig. 1. Disaster map of Dusun Nasiri and possible evacuation points.

The area with the first red gradation indicates the area most severely affected by the flash flood with a water level of 2 metres and predictions of severe damage, so that people are required to immediately evacuate themselves when a high intensity flood is occurring. The area with the second red gradation shows the flash flood affected area where severe damage is predicted with a water level of 1.5 metres. The area with orange gradation shows the flash flood area categorized with a medium damage prediction, and a water level of 1 metre. The area with yellow gradation shows the affected area categorized with slight damage predicted and a water level of 0.5 metres.

The three hamlets (Dusun) affected by disaster have semi-permanent buildings, a narrow road and narrow spaces between the buildings. These are some of the factors which will cause difficulties people trying to evacuate. Flash flood disaster mitigation efforts in those hamlets have not hitherto been conducted well by the Government of Western Seram District and by the Provincial Government of Maluku located in Ambon. An evacuation route map is needed to minimize casualties from flash floods. An evacuation route is based on the easiest way to get to the safest place from the danger of flash floods and is developed with the use of ArcGIS software. Planning for flash flood evacuation locates an area in each hamlet that has a height of +15 metres and is far away from the river. The height +15 metres is considered high enough for a place safe from the flood. Figure 1 shows the evacuation points. 
Table 1. The trip time from the origin point to the evacuation area of Dusun Nasiri

\begin{tabular}{|c|c|c|c|c|}
\hline \multirow{2}{*}{ 苍 } & \multirow{2}{*}{$\begin{array}{c}\text { Destination Point } \\
\text { (Evacuation } \\
\text { Area) }\end{array}$} & \multirow{2}{*}{$\begin{array}{l}\text { Distance } \\
\text { (metres) }\end{array}$} & \multicolumn{2}{|c|}{ Trip Length } \\
\hline & & & minutes & seconds \\
\hline A & 1 & 123 & 2 & 44 \\
\hline B & 2 & 203 & 4 & 31 \\
\hline $\mathrm{C}$ & 2 & 209 & 4 & 39 \\
\hline $\mathrm{D}$ & 2 & 184 & 4 & 5 \\
\hline $\mathrm{E}$ & 1 & 123 & 2 & 44 \\
\hline
\end{tabular}

Fig. 1. shows the distance between the evacuation point and the evacuation area. Trip length is based on the walking speed of a group of people, which is $0.75 \mathrm{~m} /$ second. The distance of each point to the evacuation area can be seen on the map, and the trip length from the point of origin to the evacuation area can be calculated (Table 1). On TABLE 1 it can be seen that the trip length to reach the evacuation area from the furthest point is still short enough at 8 minutes 36 seconds. Therefore, a disaster early warning system needs to provide a flash flood warning flood 10 minutes in advance.

All the evacuation locations are nearby privately owned farms considered to be safe from the impacts of a flash flood. The routes to them are the steep uphill roads that people use to go to and from their farms. It could be said that access to the safe area does not complete the evacuation process. Facilities and infrastructure are needed. The main infrastructure that has to be constructed first is the steps as can be seen in Fig. 2. The second is the direction sign boards that can be seen in Fig. 3.

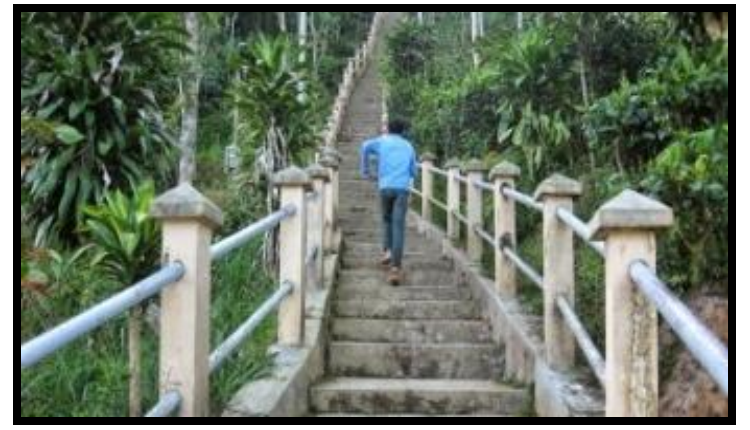

Fig. 2. Example of the steps for disaster victims to climb to get to the safest area (evacuation area)

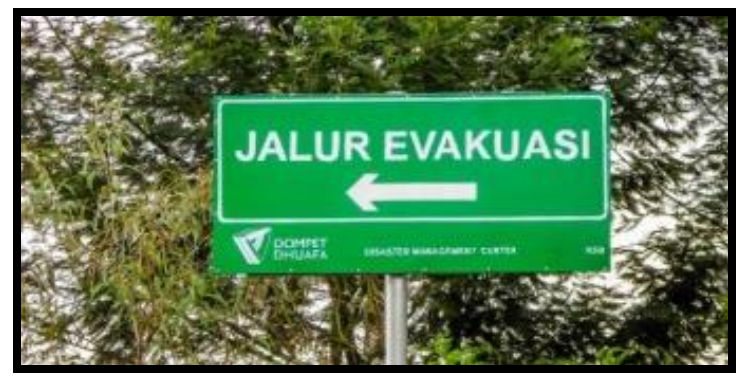

Fig. 3. Example of a direction sign on an evacuation route 


\section{Mitigation and aid distribution routes}

\subsection{Alternative 1 (the existing route)}

Access to the disaster location in Huamual Sub-District, Western Seram District of the City of Ambon, by the existing route is not effective in terms of time (see Table 2). This is because the disaster areas are located on an island and cannot be reached by land. In addition to the long distance to the location of the flash flood, both from the Centre of Western Seram Government and from the Centre of Maluku Provincial Government, there is also the condition of the roads which can no longer to be crossed by a four-wheeler, but only by using two-wheeled vehicle and then continuing on foot. The condition of existing road network and alternative routes is shown in Fig. 4.

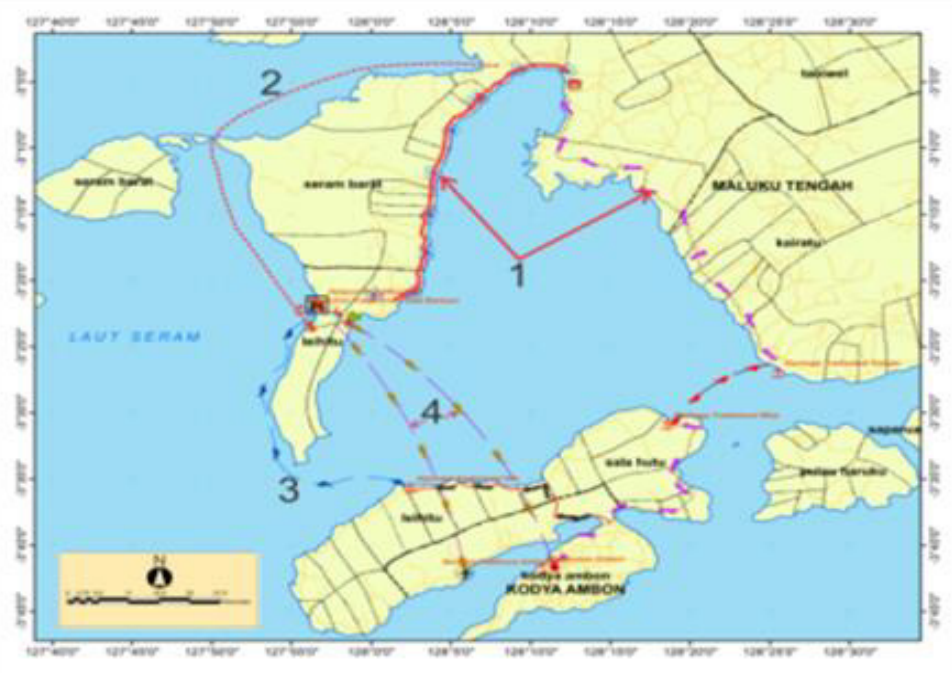

Fig. 4. Transport route alternatives to the disaster location

Table 2. Trip length from Ambon City - disaster location (alternative 1 or the existing condition)

\begin{tabular}{|c|c|c|c|c|c|}
\hline \multirow[t]{2}{*}{ No } & \multirow{2}{*}{$\begin{array}{c}\text { Origin } \\
- \\
\text { Destination }\end{array}$} & \multirow{2}{*}{$\begin{array}{c}\text { Transport } \\
\text { Mode }\end{array}$} & \multirow{2}{*}{$\begin{array}{c}\text { Distance } \\
(\mathbf{K m})\end{array}$} & \multicolumn{2}{|c|}{ Trip Length } \\
\hline & & & & Hrs & Min \\
\hline 1 & Ambon City - ASDP & Car & 33.92 & 1 & 30 \\
\hline 2 & ASDP -ASDP & Ferry & 14.24 & 2 & 0 \\
\hline 3 & ASDP - Western Seram District & Car & 56.51 & 2 & 0 \\
\hline 4 & $\begin{array}{c}\text { Western Seram District -Huamual Sub- } \\
\text { District }\end{array}$ & Motor-cycle & 58.68 & 2 & 40 \\
\hline 5 & Huamual Sub-District - Location & On Foot & 7.75 & 3 & 15 \\
\hline \multicolumn{3}{|c|}{ Total } & 171.1 & $\begin{array}{l}10 \\
11\end{array}$ & $\frac{85}{25}$ \\
\hline
\end{tabular}

Source: Results of the field survey in July 2014

\subsection{Alternative 2 (sea + land transport)}

The alternative is to change from land transport mode to sea mode. Sea mode involves using the existing docks in Masika Jaya and/or Pelita Jaya which are located \pm 22.7 miles away from the Centre of Western Seram District Government in Piru City. This alternative 
was considered more effective and time-efficient in distributing aid to the affected area (see Table 3).

Table 3.The Required Trip Length from Ambon City - Disaster Location (Alternative 2)

\begin{tabular}{|c|c|c|c|c|c|}
\hline \multirow{2}{*}{ No } & Origin & Transport Mode & Distance & \multicolumn{2}{c|}{ Trip Length } \\
\cline { 4 - 6 } & $\begin{array}{c}- \\
\text { Destination }\end{array}$ & Km) & Hrs & Min \\
\hline 1 & Ambon City-ASDP & Car & 33.92 & 1 & 30 \\
\hline 2 & ASDP-ASDP & Ferry & 14.24 & 2 & 0 \\
\hline 3 & ASDP-Western Seram District & Car & 56.51 & 2 & 0 \\
\hline 4 & $\begin{array}{c}\text { Western Seram District - } \\
\text { Masika Jaya or Pastika Jaya }\end{array}$ & Car & 22.70 & 1 & 10 \\
\hline 5 & $\begin{array}{c}\text { Masika Jaya or Pastika Jaya- } \\
\text { Location }\end{array}$ & $\begin{array}{c}\text { Water Bus (capacity: } \\
12 \text { passengers) }\end{array}$ & 54.14 & 2 & 20 \\
\hline \multicolumn{2}{|c|}{ Total } & 181.51 & 8 & 60 \\
\cline { 5 - 6 } & \multicolumn{2}{|c|}{} & & 9 & 00 \\
\hline
\end{tabular}

Source: Results of field survey in July 2014

\section{3 Alternative 3 (sea and land transport)}

Because Maluku province is an island, transport to there is traditionally by water. One traditional dock is located in Hila Sub-District. The conditions of the road both from Ambon City and the airport to the traditional dock are adequate, since it is a national road. It is possible that to integrate sea transport with land transport modes . The planned logistical aid distribution to flood victims from Ambon to the disaster affected hamlets can be carried out by using the existing water bus and then distributing to the evacuation area by land transport already available.

The advantage of this alternative is that it does not require the provision of new facilities and infrastructure. The water bus is the daily transport for the local people who already have a traditional dock. However, there is a need to build a traditional dock in Western Seram District, especially for a disaster location. However, the existing water bus has only a small capacity, so that it cannot accommodate the large amounts of logistical aid in one trip. Thus, the government should build a traditional dock at the disaster site, and provide a water bus on standby all the time (see Table 4).

Table 4. The Required trip length from Ambon City - disaster location (alternative 3)

\begin{tabular}{|c|c|c|c|c|c|}
\hline No & $\begin{array}{c}\text { Origin } \\
- \\
\text { Destination }\end{array}$ & Transport Mode & Distance & \multicolumn{2}{c|}{ Trip Length } \\
\cline { 5 - 6 } & $\begin{array}{c}\text { Ambon City - } \\
\text { Hilla Traditional Dock }\end{array}$ & Car & Hrs & Min \\
\hline 2 & $\begin{array}{c}\text { Hilla Traditional Dock- } \\
\text { Location }\end{array}$ & $\begin{array}{c}\text { Water Bus (capacity: } 12 \\
\text { passengers) }\end{array}$ & 41.45 & 1 & 30 \\
\hline \multicolumn{2}{|r|}{ Total } & 73.66 & 2 & 60 \\
\cline { 5 - 6 } & & & 3 & 00 \\
\hline
\end{tabular}

Source: Results of the field survey in July 2014

\section{4 Alternative 4 (air transport)}

The fourth alternative is the mode of air transport. The logistical aid from the central government was distributed using airplanes from Soekarno Hatta Airport (Jakarta) to Pattimura Airport (Ambon) and then distributed by helicopter at the location of the study. 
For helicopters from Pattimura Airport to land there, a heliport would need to be constructed.

The use of air transport in the distribution of logistical aid to the flash flood disasterprone locations has some advantages in terms of trip length (see Table 5) However, applying this third alternative requires a helicopter to distribute the logistical aid from Pattimura Airport (Ambon) and a heliport in the evacuation area for the helicopter to land with the aid.

Table 5. The required trip length from Ambon City - disaster location (alternative 4)

\begin{tabular}{|c|c|c|c|c|c|}
\hline \multirow{2}{*}{ No } & Origin & \multirow{2}{*}{$\begin{array}{c}\text { Transport } \\
\text { Mode }\end{array}$} & Distance & \multicolumn{2}{c|}{ Trip Length } \\
\cline { 4 - 6 } & - Destination & Km & Hr & Min \\
\hline 1 & Ambon City-Location & Helicopter & 41.00 & 0 & 25 \\
\hline \multicolumn{2}{|c|}{ Total } & 41.00 & 0 & 25 \\
\hline
\end{tabular}

\section{Comparison of alternatives}

The selection of the alternatives focused more on the trip length needed to reach the disaster location than on considering the cost. It can be seen on Table 6 .

Table 6. Comparison of the alternatives

\begin{tabular}{|c|c|c|c|}
\hline \multirow{2}{*}{ Parameter } & \multicolumn{3}{|c|}{ Transport Mode } \\
\hline & Land & Sea & Air \\
\hline Distance & $\begin{array}{l}\text { Land distance: } \\
\quad \pm 171.1 \mathrm{~km}\end{array}$ & $\begin{array}{l}\text { Land distance: } 41.45 \mathrm{~km} \\
\text { Sea distance: } 32.21 \mathrm{~km}\end{array}$ & $41 \mathrm{~km}$ \\
\hline $\begin{array}{l}\text { Speed of the } \\
\text { modes used }\end{array}$ & $\begin{array}{l}\text { Land Transport: } 30 \\
\qquad \mathrm{~km} / \mathrm{hr}\end{array}$ & $\begin{array}{l}\text { Land Transport: } 30 \mathrm{~km} / \mathrm{h} \\
\text { Sea Transport }: 30 \\
\mathrm{~km} / \mathrm{h}\end{array}$ & $100 \mathrm{~km} / \mathrm{hour}$ \\
\hline Trip length * & $\begin{array}{c}\text { Land Transport: } - \pm 11 \\
\text { hours }\end{array}$ & $\begin{array}{c}\text { Land Transport: } 1.5 \text { hours; } \\
\text { Sea Transport }: 1.5 \\
\text { hours } \\
\text { Total: } 3 \text { hours }\end{array}$ & 25 minutes \\
\hline $\begin{array}{c}\text { Infra- } \\
\text { structure }\end{array}$ & $\begin{array}{l}\text { Using a winding } \\
\text { national road and } \\
\text { then continuing by } \\
\text { using the provincial } \\
\text { and district roads as } \\
\text { in the Table } 5.1\end{array}$ & $\begin{array}{l}\text { Using a winding national } \\
\text { road and the traditional } \\
\text { dock in Hila Village. } \\
\text { However, a traditional dock } \\
\text { in Dusun Talaga is needed }\end{array}$ & $\begin{array}{l}\text { No heliport in the } \\
\text { disaster location. } \\
\text { Heliport infra-structure } \\
\text { is needed in Dusun } \\
\text { Talaga as it is safe from } \\
\text { disaster- }\end{array}$ \\
\hline
\end{tabular}

* Assuming no obstacles are encountered

** Assuming that the roads are navigable.

From the point of view of the time it takes to distribute logistical, medical and paramedical aid, a helicopter clearly has the fastest delivery time than the other available modes of transport. The heliport should be constructed in Dusun Talaga which lies between the affected hamlets.

The use of air transport is planned for logistical, medical and paramedical distribution only in urgent conditions. Sea transport is also used.

Dusun Talaga hamlet is safe from flash flood disaster, so the following are proposed:

- To improve the traditional dock at Dusun Talaga.

- To build a heliport near the traditional dock. 
In order to accelerate the evacuation process and the distribution of aid to flash flood victims, good access the evacuation area is needed. Therefore, the transport network, especially land transport needs to be restored.

\section{Conclusions and suggestions}

The results of the analysis and discussion that has been conducted lead to the following conclusions:

This study has resulted in the most efficient evacuation route map for the escape from each hamlet in the event of flood disaster. In general, the evacuation route uses the village roads with a width of \pm 3 metres. The evacuation route heads toward the evacuation area located on the edge of the settlements. The evacuation area is located on 15 metres above sea level. In more detail, the evacuation route for each hamlet is as follows:

Dusun Nasiri

There are two evacuation areas. The first can be reached by people with the furthest point of origin (Point B) in 8 minutes 36 seconds. The second can be reached from the furthest point of origin (Point E) in 4 minutes 21 seconds. Consequently, the early warning system for flash flood needs to be at least 10 minutes in advance.

Dusun Mange-mange

There are two evacuation areas. The first can be reached by people from the furthest point of origin (Points A and E) in 2 minutes 44 seconds. The second can be reached in 4 minutes 39 seconds. Consequently, the early warning system for flash flood needs to give warning at least 10 minutes in advance.

\section{Dusun Hatamanu}

There are three evacuation areas. The first can be reached by people starting from the furthest point of origin (Point D) in 6 minutes 49 seconds. The second can be reached by people from the furthest point of origin (Point B) in 4 minutes 36 seconds. The third can be reached by people from the furthest point of origin in 2 minutes 43 seconds. Consequently, the early warning system for the flash flood needs to give an early warning at least 10 minutes in advance.

The distribution of logistical, medical and paramedical aid during the emergency responses uses air transport which is a helicopter that can reach the area in 25 minutes from the centre of Ambon City and Pattimura Airport. This requires the heliport facility which is planned for construction in the Dusun Talaga. Non-urgent aid distribution is planned using a combination of land and sea transport modes (Alternative 3) that can reach the disaster location in 3 hours from the centre of Ambon City. If the distribution comes from West Seram District, the plan would be to use sea transport modes (Alternative 2) which can reach the location in 3 hours 30 minutes. Therefore, to facilitate aid distribution, an infrastructure is required for water buses to move closer to the beach (a dock). This infrastructure need calls for a traditional dock to be constructed in Dusun Talaga.

In general, the problems along the road from the Office of Western Seram District Government to the Huamual Sub-District Office and their solutions are as follows:

- Road damage caused by the water left by rainfall. The solution is to build drainage and then restore the damaged roads.

- Road damage caused by the landslides from the cliff. The solution is to stabilise the cliff.

- Lost bridges and those sufficiently damaged so as to be unsafe. The solution is to construct new bridges or provide a surface on the courses of the bridges and the river wall. 
- Partial blocking of the road which makes the road inaccessible to cars. The solution is to clear the road of the debris.

- Roads cut by landslides and uncleared debris. The solution is to carry out reforestation in the headwaters area and also to harden the cliff after a soil test has been conducted.

- Damage to the road through the middle of the forest. The solution is to plan to plant productive trees that can encourage people's economic activity, then to rebuild the road network to accelerate economic growth, after studying and restoring the forest's water flow system.

The authors make the following suggestions for improving the quality of this study:

- The involvement of geographers is required so that the mapping will be more appropriate.

- The structure of the evacuation route steps needs to be designed.

- Further study is needed of the road structure.

- More time to be added to the survey period in order to increase familiarity with the location under study.

\section{Acknowledgements}

I would like to give my sincere thanks to Gadjah Mada University and the New Zealand Foreign Affairs \& Trade Aid Programme for providing the opportunity to join the research project Community Resilience and Economic Development Programme, Capacity Development on Natural Disaster Risk Management for Communities in Small Islands.

\section{References}

1. Karnawati D. Bencana Alam Gerakan Massa Tanah di Indonesia dan Upaya Penanggulangannya. Yogyakarta:Penerbit Jurusan Teknik Geologi Fakultas Teknik UGM. (2005)

2. Departemen Komunikasi dan Informatika, Badan Informasi Publik. Memahami Bencana, Informasi Tindakan Masyarakat Mengurangi Resiko Bencana. Jakarta:Pusat Informasi Kesejahteraan Rakyat. (2008)

3. Yamashita, N., \& Ohmoto T. Local People's Responses to Flood Disasters in Flood Prone Areas of Northeast Bangladesh. Journal of Disaster Research 109(2), 288-298. (2015)

4. Yi, C., Park, R., Murao, O. \& Okamoto, E. Emergency Management: Building an O-D Ranking Model Using GIS Network Analysis. Journal of Disaster Research 7(6), 793802. (2012)

5. Mizuki, C.Flood Risk Communication from the Viewpoint of Disaster Prevention Awareness in an Urban Area of Tokyo, Kita Ward, Journal of Disaster Research 7(5), 595-603. (2012)

6. Susanto, S. Disaster Management dari Negeri Rawan Bencana. Jakarta:PT. Aksara Grafika Pratama. (2006)

7. Compos, V. A Method for Evacuation Route Planning in Disaster Situations. 15th Meeting of the Euro Working Group on Transport. Procedia-Social and Behavioral Science 54, pp. 503-512. (2012)

8. Variadi, V. Kajian rencana evakuasi dalam kesiapsiagaan bencana tsunami dengan pendekatan berbasis masyarakat (Studi Kasus: Kecamatan meuraksa kota Banda Aceh). Yogyakarta: Tesis Pasca Sarjana Fakultas Teknik Universitas Gadjah Mada. (2010) 
9. Stevanov, A., \& Smith, J. Multi Objective Evacuation Routing in Transport Networks. European Journal of Operational Research 1498, 435-446. (2009)

10. Budiarjo, A.Evacuation Shelter Building Planning for Tsunami- Prone Area, Case Study of Meulaboh City Indonesia'. Master's Degree Thesis, International Institute for Geo-Information Science and Earth Observations, ITC, Enschede. (2006)

11. Munawar, A. Dasar-dasar Teknik Transportasi. Yogyakarta:Beta Offset. (2011)

12. Sukirman, S. Beton Aspal Campuran Panas. Jakarta, Penerbit Granit (2003) 